\title{
Late-onset Pompe disease: what is the prevalence of limb-girdle muscular weakness presentation?
}

\author{
Doença de Pompe de início tardio: qual é a prevalência na apresentação de fraqueza \\ muscular de cinturas?
}

Paulo José Lorenzoni', Cláudia Suemi Kamoi Kay, Nádia Sugano Higashi', Vânia D’Almeida², Lineu Cesar

Werneck ${ }^{1}$, Rosana Herminia Scola ${ }^{1}$

\begin{abstract}
Pompe disease is an inherited disease caused by acid alpha-glucosidase (GAA) deficiency. A single center observational study aimed at assessing the prevalence of late-onset Pompe disease in a high-risk Brazilian population, using the dried blood spot test to detect GAA deficiency as a main screening tool. Dried blood spots were collected for GAA activity assay from 24 patients with "unexplained" limb-girdle muscular weakness without vacuolar myopathy in their muscle biopsy. Samples with reduced enzyme activity were also investigated for GAA gene mutations. Of the 24 patients with dried blood spots, one patient (4.2\%) showed low GAA enzyme activity (NaG/AaGIA: 40.42; $\% \mathrm{INH}: 87.22 \%$ ). In this patient, genetic analysis confirmed two heterozygous mutations in the GAA gene (c.-32-13T>G/p.Arg854Ter). Our data confirm that clinicians should look for late-onset Pompe disease in patients whose clinical manifestation is an "unexplained" limb-girdle weakness even without vacuolar myopathy in muscle biopsy.
\end{abstract}

Keywords: glycogen storage disease type II; muscular weakness; muscle diseases.

\section{RESUMO}

A doença de Pompe é uma doença hereditária causada pela deficiência da enzima alfa-glicosidase ácida (GAA). Estudo observacional foi realizado, em um único centro, para determinar a prevalência da doença de Pompe de início tardio (LOPD) em uma população brasileira de alto risco, usando teste em gota seca (DBS) como ferramenta principal de triagem para detectar a deficiência da GAA. DBS foi coletado para avaliar a atividade da GAA em 24 pacientes com fraqueza muscular de cinturas "não explicada" sem miopatia vacuolar na biópsia muscular. As amostras com atividade enzimática reduzida foram também submetidas a análise de mutações no gene GAA. Dos 24 pacientes com DBS, baixa atividade da enzima GAA (NaG/AaGIA: 40.42; \%INH: 87.22\%) foi encontrada em um paciente (4.2\%). Nessa paciente, a análise genética confirmou duas mutações em heterozigose composta no gene GAA (c.-32-13T > G/p.Arg854Ter). Nossos resultados confirmam que LOPD deve ser investigada quando a manifestação clínica é uma fraqueza muscular de cinturas “não explicada”, mesmo na ausência de miopatia vacuolar na biópsia muscular.

Palavras-chave: doença de depósito de glicogênio tipo II; debilidade muscular; doenças musculares.

Pompe disease (PD), or glycogen storage disease type II, is a rare inherited autosomal recessive disease caused by a deficiency in acid alpha-glucosidase (GAA) enzyme leading to lysosomal glycogen storage $\mathrm{e}^{1,2}$. Pompe disease can be diagnosed by measuring GAA levels or by identifying pathogenic variants in the $G A A$ gene ${ }^{1,2}$. The late-onset phenotype results from an incomplete GAA deficiency, which appears later in childhood, in adolescence or in adulthood. The diagnosis of late-onset Pompe disease (LOPD) is still challenging and often quite delayed. It is not unusual for patients to go undiagnosed for many years as screening for PD is often overlooked or delayed in adults s,3,4,5,6,7,8. $^{2}$.

The clinical manifestation and laboratory findings vary with age and the degree of enzyme deficiency and, in some cases, the clinical presentation can mimic other neuromuscular disorders, such as limb-girdle muscular dystrophy (LGMD),

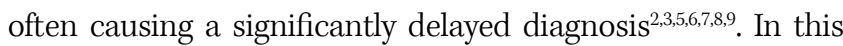
situation, muscle biopsy can help differentiate between these

\footnotetext{
¿Universidade Federal do Paraná, Hospital de Clínicas, Departamento de Clínica Médica, Serviço de Neurologia, Serviço de Doenças Neuromusculares, Curitiba PR, Brasil;

${ }^{2}$ Universidade Federal de São Paulo, Departamento de Psicobiologia, Laboratório de Erros Inatos do Metabolismo, São Paulo SP, Brasil.

Correspondence: Rosana Hermínia Scola; Serviço de Doenças Neuromusculares, Hospital de Clínicas da UFPR; Rua General Carneiro 181 / 30 andar; $80060-$ 900 Curitiba PR, Brasil; E-mail: rosana.scola@hc.ufpr.br

Conflict of interest: There is no conflict of interest to declare.

Support: This study was supported by UFPR, Fundação Araucária, CAPES and CNPq. Genetic analysis (GAA gene) was supported by Sanofi Genzyme.

Received 29 June 2017; Received in final form 22 September 2017; Accepted 10 January 2018.
} 
diseases because PD is usually associated with vacuolar myopathy with glycogen storage and the increased activity of acid phosphatase ${ }^{1,10}$. However, in some LOPD patients, the classical features are not present in the muscle biopsy because the adult form of the disease demonstrates fewer or no muscle fibers with vacuoles compared to the infantile or childhood forms; therefore, these patients may be erroneously diagnosed ${ }^{1,3,5,9,10}$.

The main objective of this study was to assess the prevalence of LOPD in a high-risk Brazilian population with "unexplained" limb-girdle muscular weakness, using the dried blood spot (DBS) test as a screening tool to detect a GAA deficiency.

\section{METHODS}

All the patients were recruited from the outpatient clinic of a single neuromuscular disorder center at the Hospital de Clínicas of the Federal University of Paraná (Curitiba, Brazil). The inclusion criteria for selected patients were limb-girdle muscle weakness, muscle biopsy with the absence of vacuolar myopathy, no affected relatives and no definitive diagnosis of limb-girdle muscular weakness. We excluded patients with a confirmed diagnosis of other neuromuscular diseases, patients with relatives diagnosed with PD, with relatives with known neuromuscular disorders, or patients younger than 18 years old. All studies were conducted in accordance with ethical principles after obtaining patient consent in the outpatient clinic.

Relevant data, including age, gender, serum creatine kinase (CK) levels, electromyographic findings and muscle histopathology were recorded at the investigation of limb-girdle muscular weakness.

Muscle biopsies were performed on the quadriceps or biceps brachialis muscles. The muscle biopsy samples were frozen in liquid nitrogen. Fresh frozen cryostat sections were stained using histology and histochemistry according to standard procedures ${ }^{11}$. Immunohistochemistry was performed for dystrophin, dysferlin, sarcoglycans and caveolin-3.

Blood samples were collected from peripheral veins in heparin-coated vacuum tubes, and the blood was immediately spotted onto filter paper (Whatman 903). The GAA enzyme activity in the DBS was assayed according to standard procedures adapted from the method described by Chamoles et al. ${ }^{13}$ apud Müller et al. ${ }^{12}$ and Turaça et al. ${ }^{14}$. The main difference in the technique was that we used acarbose to inhibit the total GAA activity ${ }^{12}$. Enzymatic activities were expressed as the ratio of neutral and acid lysosomal isoforms (NaG/AaGIA) and the inhibition percentage of the total acid fraction (\%INH). The ratio between acid and neutral alpha-glucosidase isoforms was used to separate the true-positive from false-positive cases. The previously established values within 95\% confidence interval (CI), such as deficient enzyme activity, were $\mathrm{NaG} / \mathrm{AaGIA}>40$ and \%INH > $87 \%{ }^{12}$. The results of $\mathrm{NaG} / \mathrm{AaGIA}>40$ and $\% \mathrm{INH}<87$ or NaG/ AaGIA $<40$ and $\%$ INH $>87$ were considerate undetermined (grey zone). When the results of this analysis were considered to indicate a deficiency of enzyme activity, a blood sample was obtained for a second test enzyme assay on blood lymphocytes and/or genetic analysis of the $G A A$ gene.

The data were analyzed using descriptive statistical methods. Results are presented as mean $( \pm \mathrm{SD})$ or median, as appropriate. Statistical significance was assessed by the Mann-Whitney test for continuous variables and the $\chi^{2}$-test for categorical variables. The statistical significance for all calculations was set at a $\mathrm{p}<0.05$ value with a 95\% CI.

\section{RESULTS}

We found 24 patients with "unclassified" limb-girdle muscular weakness in our center who were eligible for laboratory screening for LOPD. The sample population consisted of 24 patients (nine females and 15 males), aged 18 to 72 years (median: 39 years; mean: $38.7 \pm 19.1$ ); age at onset varied between one and 57 years, with a mean of $21.8 \pm 17.8$ years; the duration of follow-up in our hospital varied between four and 34 years, with a mean of $14.1 \pm 7.8$ years (Table).

Table. Characteristics of the patients studied with normal and deficient GAA activity.

\begin{tabular}{|c|c|c|}
\hline Variable & $\begin{array}{l}\text { Normal GAA } \\
\text { activity }\end{array}$ & $\begin{array}{c}\text { Deficient } \\
\text { GAA activity }\end{array}$ \\
\hline Number of patients & 23 & 1 \\
\hline Gender (F : M) & 08:15 & 01:00 \\
\hline Age, years (mean \pm SD; median) & $39.0 \pm 19.5 ; 42$ & 55 \\
\hline $\begin{array}{l}\text { Age at onset, years } \\
\text { (mean } \pm \text { SD; median) }\end{array}$ & $21.7 \pm 18.2 ; 19$ & 25 \\
\hline $\begin{array}{l}\text { Time of follow-up, years } \\
\text { (mean } \pm \text { SD; median) }\end{array}$ & $14.3 \pm 7.9 ; 15$ & 1 \\
\hline $\begin{array}{l}\text { Serum CK level, U/L } \\
\text { (mean } \pm \mathrm{SD} \text {; median) }\end{array}$ & $\begin{array}{c}2315.0 \pm 3032.4 \\
1023\end{array}$ & 1,467 \\
\hline \multicolumn{3}{|l|}{ Needle electromyography } \\
\hline myopathic features & 10 & 1 \\
\hline mixed features* & 4 & 0 \\
\hline myotonic discharge & 1 & 1 \\
\hline normal & 9 & 0 \\
\hline \multicolumn{3}{|l|}{ Muscle biopsy features } \\
\hline type 1 and 2 fiber atrophy & 2 & 0 \\
\hline type 1 fiber atrophy & 0 & 1 \\
\hline type 2 fiber atrophy & 4 & 0 \\
\hline recent and chronic denervation & 3 & 0 \\
\hline chronic myopathy & 5 & 0 \\
\hline active myopathy & 4 & 0 \\
\hline chronic and active myopathy & 2 & 0 \\
\hline myopathy with denervation & 3 & 0 \\
\hline increased acid phosphatase & 8 & 1 \\
\hline \multicolumn{3}{|l|}{ DBS analysis (mean $\pm \mathrm{SD}$; median) } \\
\hline NaG/AaGIA ratio & $16.1 \pm 6.6 ; 14.6$ & 40.4 \\
\hline$\% \mathrm{INH}$ & $76.7 \pm 6.8 ; 76.7$ & 87.2 \\
\hline
\end{tabular}


Serum CK levels were elevated in 19 patients and normal in the remaining five patients (mean: 2,240.5 $\pm 2,989.8 \mathrm{U} / \mathrm{L}$; median: $970.5 \mathrm{U} / \mathrm{L}$; range: 85.0 to $12,610.0 \mathrm{U} / \mathrm{L}$ ) (Table).

The needle electromyographic pattern showed myopathic features in 11 patients, mixed features (myopathic and denervation) in four patients, and was normal in the remaining nine patients. Myotonic discharge occurred in two patients (Table).

In muscle biopsy, the abnormalities found were: type 1 and 2 fiber atrophy (2), type 1 fiber atrophy (1), type 2 fiber atrophy (4), recent and chronic denervation (3), chronic myopathy (5), active myopathy (4), chronic and active myopathy (2), and myopathy with denervation features (3) (Table). Muscle biopsy abnormalities were associated with increased acid phosphatase activity in muscle fibers in nine patients (Table).

Dried blood spot analysis for GAA activity revealed normal values for the NaG/AaGIA ratio (mean: $16.1 \pm 6.6$; median: 14.3; range: 6.7 to 37.3 ) and \% INH (mean: $76.7 \% \pm 6.8 \%$; median: $76.7 \%$; range: $58.1 \%$ to $85.0 \%$ ) in 23 patients (95.8\%) (Table). Deficient GAA activity (NaG/AaGIA: 40.4; \%INH: $87.2 \%$ ) was detected in only one patient (4.2\%) (Table). Patients with undetermined results (grey zone) in the DBS test were not found in our samples. Figure 1 shows the enzyme activity in all patients.

Statistical significance was found when GAA activity was deficient ( $p=0.019$ ). There is no statistical significance between patients with normal and deficient GAA activity for the remaining data.

The description of the one confirmed LOPD patient is as follows: The affected patient in our study was a 55-year-old woman (African descendant) who presented with mild myalgia and proximal lower limb weakness, and reported falls occurring mainly when walking for long distances, and difficulty climbing stairs since the age of 25 years. She had mild dysphagia after the age of 50 years. There were no delayed motor milestones or relatives with similar symptoms. She had hypertension, diabetes and dyslipidemia. Neurological examination showed normal Mini-Mental State Examination score (27/30), calf pseudohypertrophy, mild symmetrical weakness in proximal muscles in the lower limbs (Medical Research Council grade 4); axial muscle weakness in Gowers' maneuver, diffusely reduced deep tendon reflexes, and a myopathic gait. The initial diagnosis was LGMD and the investigation yielded the following results: increased serum CK levels (1,467U/L; normal: $\leq 200 \mathrm{U} / \mathrm{L})$; needle electromyography revealed motor unit potentials with low amplitude and short duration in the iliopsoas muscle associated with fibrillation and short myotonic discharge potentials in lumbar paraspinal muscles; the next generation sequencing customized panel for the main genes related to LGMD was negative; and muscle biopsy showed mild type 1 muscle fiber atrophy associated with increased acid phosphatase activity in some muscle fibers (Figure 2). She was diagnosed as "unclassified” LGMD. Follow-up investigation revealed a deficiency in the activity of the GAA enzyme (NaG/AaGIA ratio: 40.4\%; \%INH: 87.2\%), which was also confirmed in another fluorimetric assay in the same sample (1.86umol/L/h; normal: > $4.0 \mathrm{umol} / \mathrm{L} / \mathrm{h}$ ) and in a second sample (0.88 mcmol/20H/L; normal: 8.53-35.40 mcmol/20H/L). She underwent targeted gene sequencing (next generation sequencing) for the $G A A$ gene, which revealed two pathogenic variants (compound heterozygous): the c.-32-13T $>\mathrm{G}$ variant in the splice site of intron 1 and the c.2560C $>\mathrm{T}$ (p.Arg854Ter/ R854X) nonsense variant in exon 18. We diagnosed LOPD based
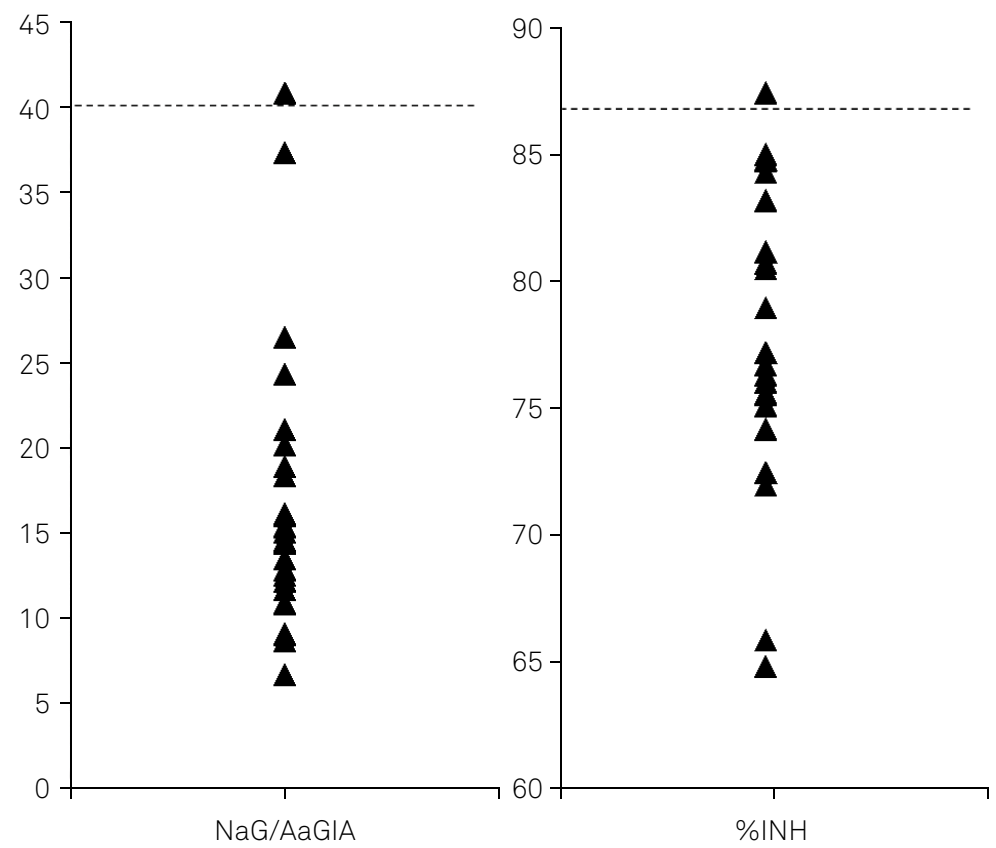

Figure 1. Acid alpha-glucosidase (GAA) activities of the patients studied were expressed as the ratio of neutral and acid lysosomal isoforms ( $\mathrm{NaG} / \mathrm{AaGIA}$ ) and the inhibition percentage of the total acid fraction (\%INH). The line indicates the values established, such as deficient enzyme activity. 
on clinical data and laboratory screening, which was confirmed by genetic analysis as well. She does not currently use enzyme replacement therapy. In the follow-up, other family members
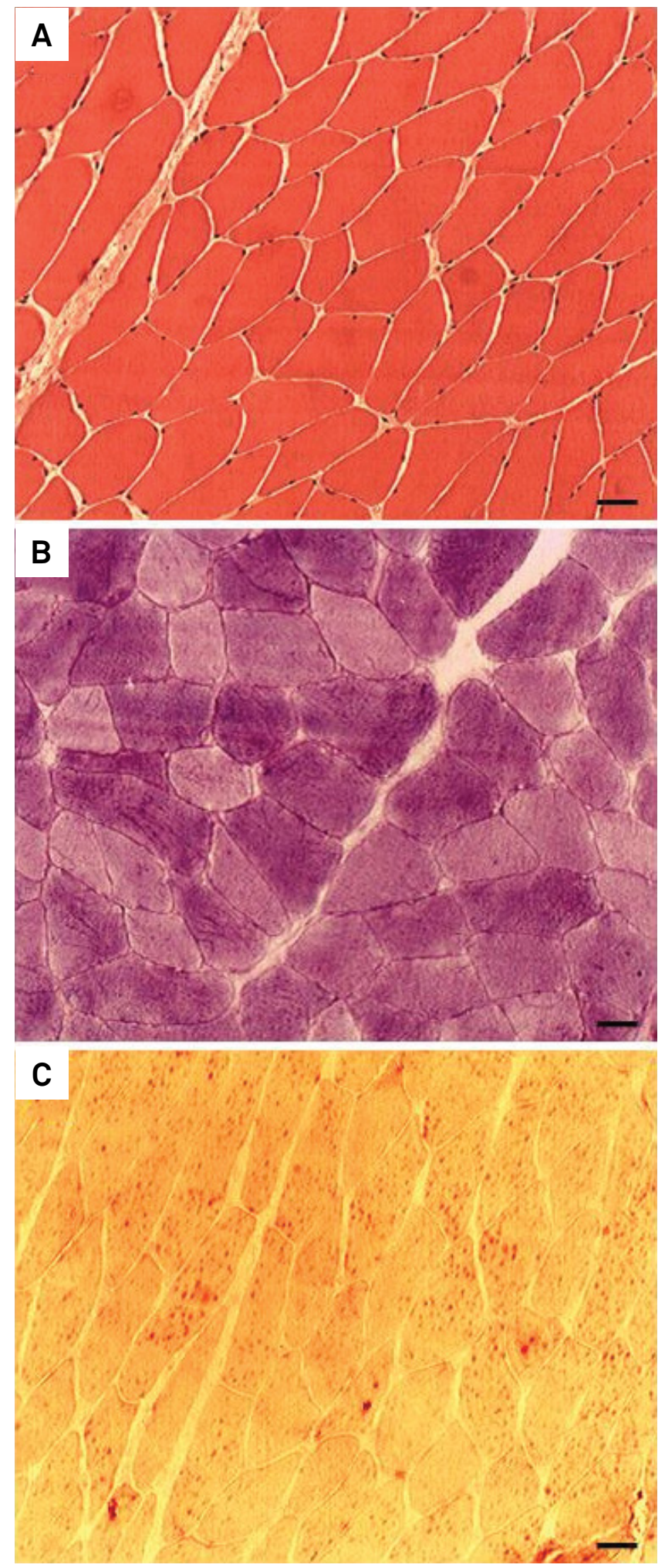

Figure 2. Muscle biopsy from the LOPD patient shows no vacuolated muscle fibers associated with increased acid phosphatase activity in muscle fibers (A: Hematoxylin-eosin stain; B: Periodic acid-Schiff stain; C: Acid phosphatase stain). Bar $=50$ um. were also screened for GAA deficiency and one sister was diagnosed as LOPD, based on a deficiency of GAA activity and pathogenic variants in the same compound heterozygous pattern (c.32-13T>G/p.Arg854Ter) detected in the GAA gene.

\section{DISCUSSION}

Muscle biopsy is still performed in the investigation of the main differential diagnosis of limb-girdle muscular weakness, and a PD diagnosis is considered when vacuolar myopathy with glycogen accumulation, associated with increased acid phosphatase activity (lysosomal dysfunction), either in vacuoles or focal areas, is found ${ }^{1,4,9}$. However, muscle biopsy abnormalities in PD vary with the level of GAA deficiency, the clinical type (which is also related to the enzyme level) and the disease duration ${ }^{1,10}$. In LOPD, vacuole frequency has been reported to range from $10 \%$ to $50 \%$ of patient fibers ${ }^{1,10}$. However, muscle biopsy can also present with less than $1 \%$ or no vacuolated fibers ${ }^{1,3,5,9,10,15}$. In these cases, an LOPD diagnosis may be overlooked. These reports motivated us to investigate LOPD in patients without vacuolated fibers in muscle biopsy, who were previously diagnosed with "unexplained” limb-girdle muscular weakness.

Even though our patient did not have vacuolar myopathy, her muscle biopsy showed mild non-dystrophic features (type 1 muscle fiber atrophy) associated with lysosomal dysfunction, which suggested the need to consider LOPD in the differential diagnosis.

In recent years, the use of the DBS test has made the diagnostic procedure easier and cheaper. The test has good sensitivity and specificity, regardless of the different methods used ${ }^{4,12,13,15,16,17}$. The DBS is a simple screening test that has been suggested as the first step for the diagnosis of LOPD $^{5,10,15,16}$. In our study, the DBS assay was useful in the LOPD diagnosis. To make sense of the diagnosis, the DBS test should be used in the screening of "unexplained" limb-girdle muscular weakness and "undetermined" myopathy. If screening with the DBS test is abnormal, confirmation of the diagnosis of LOPD must be achieved by means of enzymatic activity in isolated lymphocytes or analysis of the $G A A$ gene.

An early PD diagnosis is essential because GAA enzyme replacement therapy is available nowadays and there is evidence to suggest that treatment should be started early to get the best effect. However, LOPD is typically diagnosed years after the onset of initial symptoms ${ }^{5,9}$. The prevalence of undiagnosed LOPD in patients with "unclassified" LGMD and/or hyperCKemia varies from $0.8 \%$ to $4.6 \%$ in different countries, with a combined prevalence of $2.5 \%$. $^{3,4,5,7,8,10,15,16}$ The pediatric population with limb-girdle muscular weakness and/or hyperCKemia has been screened for PD by DBS as well ${ }^{17}$.

In patients with "unclassified" LGMD, the prevalence of undiagnosed LOPD varies from $2 \%$ to $8 \%$ in European cohorts $^{3,5,6,8,15,18}$. However, in some countries, e.g. Finland, undiagnosed LOPD was not found during the screening of 
"undetermined" myopathy ${ }^{19}$. The prevalence varies between countries, probably reflecting the frequency of LOPD for each country $3,6,8,10,15,16,17,18,19$. Our study estimates the prevalence of undiagnosed LOPD to be $4.2 \%$ in southern Brazilian patients with "unexplained" limb-girdle weakness, from our centre.

Screening for LOPD has also been performed in patients with either unexplained serum CK elevation, unexplained myopathy on muscle biopsy or restrictive respiratory insufficiency ${ }^{3,5,6,8,16,19}$. However, LOPD was more rare in these groups than in patients with “unclassified" LGMD, varying from $0.35 \%$ to $2.5 \%$ 3,5,6,8,15.

Genetic analysis confirmed two pathogenic variants in the $G A A$ gene in our patient. The mutation c. $-32-13 \mathrm{~T}>\mathrm{G}$ is by far the most frequent worldwide pathogenic variant in the GAA gene and the R854X is a well-documented AfricanAmerican mutation ${ }^{8,10,14,20}$. Both mutations were previously reported in association with PD in Brazilian patients ${ }^{14,20}$.

Recently, some studies have proposed using next generation sequencing to screening PD in patients with limb-girdle muscular weakness as it is faster and more cost-effective than
Sanger sequencing ${ }^{2,14}$. Although more studies need to be performed to establish its place in the investigation of LOPD, next generation sequencing has the advantage of diagnosing other causes of limb-girdle muscular weakness as well. However, the DBS test for GAA is a reliable diagnostic procedure that is noninvasive, easier, faster and cheaper, and is still considered a helpful tool as the first line screening specific for PD.

Our study was limited by the small number of patients and regional data collection from southern Brazil. Studies on $\mathrm{PD}$ are not very common in Brazil. We believe that is necessary to extend this type of study to many more clinical centers to further quantify the prevalence of undiagnosed LOPD in the Brazilian population.

\section{Acknowledgments}

The laboratory team of the LEIM (UNIFESP) for their collaboration in the DBS analysis.

\section{References}

1. Werneck LC, Lorenzoni PJ, Kay CS, Scola RH. Muscle biopsy in Pompe disease. Arq Neuropsiquiatr. 2013 May;71(5):284-9. https://doi.org/10.1590/0004-282X20130022

2. Lévesque S, Auray-Blais C, Gravel E, Boutin M, Dempsey-Nunez L, Jacques PE et al. Diagnosis of late-onset Pompe disease and other muscle disorders by next-generation sequencing. Orphanet J Rare Dis. 2016 Jan;11(1):8. https://doi.org/10.1186/s13023-016-0390-6

3. Preisler N, Lukacs Z, Vinge L, Madsen KL, Husu E, Hansen RS et al. Late-onset Pompe disease is prevalent in unclassified limb-girdle muscular dystrophies. Mol Genet Metab. 2013 Nov;110(3):287-9. https://doi.org/10.1016/j.ymgme.2013.08.005

4. Lindberg C, Anderson B, Engvall M, Hult M, Oldfors A. Search for Pompe disease among patients with undetermined myopathies. Acta Neurol Scand. 2015 Jul;133(2):131-5. https://doi.org/10.1111/ane.12460

5. Gutiérrez-Rivas E, Bautista J, Vílchez JJ, Muelas N, Díaz-Manera J, Illa I et al. Targeted screening for the detection of Pompe disease in patients with unclassified limb-girdle muscular dystrophy or asymptomatic hyperCKemia using dried blood: A Spanish cohort. Neuromuscul Disord. 2015 Jul;25(7):548-53. https://doi.org/10.1016/j.nmd.2015.04.008

6. Lukacs Z, Nieves Cobos P, Wenninger S, Willis TA, Guglieri M, Roberts $\mathrm{M}$ et al. Prevalence of Pompe disease in 3,076 patients with hyperCKemia and limb-girdle muscular weakness. Neurology. 2016 Jul;87(3):295-8. https://doi.org/10.1212/WNL.0000000000002758

7. Musumeci O, la Marca G, Spada M, Mondello S, Danesino C, Comi GP et al. LOPED study: looking for an early diagnosis in a late-onset Pompe disease high-risk population. J Neurol Neurosurg Psychiatry. 2016 Jan;87(1):5-11. https://doi.org/10.1136/jnnp-2014-310164

8. Spada M, Porta F, Vercelli L, Pagliardini V, Chiadò-Piat L, Boffi $P$ et al. Screening for later-onset Pompe's disease in patients with paucisymptomatic hyperCKemia. Mol Genet Metab. 2013 Jun;109(2):171-3. https://doi.org/10.1016/j.ymgme.2013.03.002

9. Bembi B, Cerini E, Danesino C, Donati MA, Gasperini S, Morandi L et al. Diagnosis of glycogenosis type II. Neurology. 2008 Dec;71(23 Suppl 2):S4-11. https://doi.org/10.1212/WNL.0b013e31818da91e

10. Genge A, Campbell N. Reevaluating muscle biopsies in the diagnosis of Pompe disease: a corroborative report. Can J Neurol Sci. 2016 Jul;43(4):561-6. https://doi.org/10.1017/cjn.2016.29
11. Werneck LC. The value of muscle biopsy in neurology: a study of 290 biopsies. Rev Bras Clin Ter. 1981;10 Suppl:2-24.

12. Müller KB, Rodrigues MD, Pereira VG, Martins AM, D’Almeida V. Reference values for lysosomal enzymes activities using dried blood spots samples - a Brazilian experience. Diagn Pathol. 2010 Sep;5(1):65. https://doi.org/10.1186/1746-1596-5-65

13. Chamoles NA, Niizawa G, Blanco M, Gaggioli D, Casentini C. Glycogen storage disease type II: enzymatic screening in dried blood spots on filter paper. Clin Chim Acta. 2004 Sep;347(1-2):97-102. https://doi.org/10.1016/j.cccn.2004.04.009

14. Turaça LT, Faria DO, Kyosen SO, Teixeira VD, Motta FL, Pessoa JG et al. Novel GAA mutations in patients with Pompe disease. Gene. 2015 Apr;561(1):124-31. https://doi.org/10.1016/j.gene.2015.02.023

15. Pérez-López J, Selva-O’Callaghan A, Grau-Junyent JM, Gallego-Galindo L, Coll MJ, García-Morillo S et al. Delayed diagnosis of late-onset Pompe disease in patients with myopathies of unknown origin and/or hyperCKemia. Mol Genet Metab. 2015 Apr;114(4):580-3. https://doi.org/10.1016/j.ymgme.2015.02.004

16. Goldstein JL, Young SP, Changela M, Dickerson GH, Zhang H, Dai J et al. Screening for Pompe disease using a rapid dried blood spot method: experience of a clinical diagnostic laboratory. Muscle Nerve. 2009 Jul;40(1):32-6. https://doi.org/10.1002/mus.21376

17. Ünver O, Hacıfazlıoğlu NE, Karatoprak E, Güneș AS, Sağer G, Kutlubay $B$ et al. The frequency of late-onset Pompe disease in pediatric patients with limb-girdle muscle weakness and nonspecific hyperCKemia: A multicenter study. Neuromuscul Disord. 2016 Nov;26(11):796-800. https://doi.org/10.1016/j.nmd.2016.09.001

18. Almeida V, Conceição I, Fineza I, Coelho T, Silveira F, Santos M, et al. Screening for Pompe disease in a Portuguese high risk population. Neuromuscul Disord 2017;:S0960-8966:31014-8. https://doi.org/10.1016/j.nmd.2017.03.010

19. Palmio J, Auranen M, Kiuru-Enari S, Löfberg M, Bodamer O, Udd B. Screening for late-onset Pompe disease in Finland. Neuromuscul Disord. 2014 Nov;24(11):982-5. https://doi.org/10.1016/j.nmd.2014.06.438

20. Oba-Shinjo SM, da Silva R, Andrade FG, Palmer RE, Pomponio RJ, Ciociola KM et al. Pompe disease in a Brazilian series: clinical and molecular analyses with identification of nine new mutations.J Neurol. 2009 Nov;256(11):1881-90. https://doi.org/10.1007/s00415-009-5219-y 